\title{
Modafinil in sports: ethical considerations
}

\author{
K R Kaufman
}

Br J Sports Med 2005;39:241-244. doi: 10.1136/bjsm.2004.016303

Performance enhancing agents are prohibited in athletic competition so that only athletic skills can determine outcomes. Modafinil is a novel non-addicting psychostimulant approved for treatment of narcolepsy. Does its use, especially for medical indications, violate the Olympic Movement Anti-Doping Code? This is discussed with reference to a current high profile case.

which included unethical experimentation on minors and the specific research intent of finding means of administration of substances that would evade international control. ${ }^{56}$ The pervasive use of doping agents led to an anti-doping hot line in Sweden which clearly defined this to be a public health problem. ${ }^{7}$

This use of non-banned substances resulted in the inclusion of the phrase "related substance" to the specific banned drug list (stimulants; narcotics; anabolic agents; diuretics; peptide hormones, analogues and mimetics; masking agents; $\beta$ blockers) in the Olympic Movement AntiDoping Code (OMAC). ${ }^{89}$ Further, the Olympic Charter (effective 4 July 2003) dictates that all athletes, coaches, trainers, and officials will "comply with the provisions of the Olympic Charter regarding the World Anti-Doping Code (Rules 45 and 48)."10 But is the use of this phrase always appropriate? Further, if a "related substance" is used to treat a medical condition, would it be ethical to disqualify an athlete? The novel psychostimulant, modafinil, is a case in point.

Modafinil has shown efficacy in, and is FDA approved for, treating daytime sleepiness associated with narcolepsy, sleep apnoea/hypopnoea syndrome, and shift work sleep disorder. ${ }^{11-13}$ Additional off-label uses include treatment of sedation and fatigue in depression, ${ }^{14}{ }^{15}$ multiple sclerosis, ${ }^{16}$ myotonic dystrophy, ${ }^{17}$ opioid induced sleepiness, ${ }^{18}$ and Parkinson's disease. ${ }^{19}$ Further, modafinil has been used to treat spastic cerebral palsy, ${ }^{20}$ attention deficit hyperactivity disorder, ${ }^{21}$ and depression in monotherapy. ${ }^{22}$ Cognitive enhancement has been noted with modafinil in healthy volunteers. ${ }^{23}$ Neuroprotective qualities have been identified in mptp-animal-Parkinson models. ${ }^{24}$ The use of modafinil in reducing food intake has also been studied, with a role in treating obesity suggested. ${ }^{25}$

Unlike dextroamphetamine and methylphenidate, there does not appear to be a risk of abuse associated with modafinil. ${ }^{26}{ }^{27}$ Modafinil is a suggested treatment for amphetamine and cocaine dependence. ${ }^{28} 29$

Further, unlike dextroamphetamine and methylphenidate, the c-fos expression is limited mainly to the anterior hypothalamic nucleus, adjacent areas, and the orexin neurones. ${ }^{30-32}$ Although the specific mechanism of action for modafinil is unknown, alterations in orexin, $\gamma$ aminobutyric acid (GABA) transmission and GABA/glutamate balance have been implicated. ${ }^{33-36}$

Does use of modafinil, especially for medical indications, violate the OMAC?

\section{CASE}

In the 2003 World Track and Field Championships, a female elite sprinter (Kelli 
White) won a rare sprint double $(100 \mathrm{~m} / 200 \mathrm{~m}) .^{37}$ She tested positive for modafinil after her $100 \mathrm{~m}$ victory; however, she tested negative after her 200 m victory. ${ }^{38}{ }^{39}$ As the existence of a positive urine for modafinil was known before the $4 \times 100 \mathrm{~m}$ relay, she withdrew from that event in order that any potential sanction she might receive would not affect her team. ${ }^{40}$ This sprinter later informed the International Association of Athletics Federations (IAAF) that she was prescribed modafinil for the treatment of narcolepsy by her personal doctor and that she has a positive family history of this illness. ${ }^{41}$ The IAAF reviewed her case, felt that modafinil fell under the umbrella phrase of "related substances" for stimulants, did not accept her explanation, and referred the case onward to the member federation, USA Track and Field (USATF). ${ }^{42}{ }^{43}$ If the USATF confirms a doping offence, then this athlete will be disqualified from the competition, stripped of her two gold medals, and publicly warned. ${ }^{42}{ }^{43}$

\section{DISCUSSION}

The present case poses multiple questions. Firstly, should modafinil be considered a psychostimulant? Secondly, if it is a psychostimulant, and yet is required to treat a medical condition, should the athlete be disqualified? Thirdly, how should one verify the alleged medical diagnosis? Fourthly, what must the athlete do in order to maintain eligibility to compete when on a "banned substance?" Fifthly, should the punishments be specific or should they be tailored to specific situations? Sixthly, are we witnessing further doping scandals?

Modafinil is not a classic psychostimulant as noted by its c-fos expression, mechanisms of action, minimal abuse potential, and its use to treat amphetamine abuse. ${ }^{26-36}$ Its pharmacological profile is clearly different from standard psychostimulants. ${ }^{44}$ Nonetheless, if a psychostimulant is defined as improving cognitive functioning, wakefulness, and energy, then modafinil meets such criteria. ${ }^{23}{ }^{45}$ However, this may be too broad a definition-for example, antidepressants improve cognitive functioning, wakefulness, and energy in depressed patients. It is worthwhile noting that the narcolepsy literature differentiates psychostimulants from modafinil. ${ }^{47}$ As such, the inclusion of modafinil by OMAC-Ia (stimulants) as a "related substance" remains unclear.

However, if the athlete is using modafinil to treat a medical condition, then disqualification for having taken such would not appear, on initial evaluation, to be ethical. To not allow the use of this agent, would mean that the athlete is functioning at a handicap, for modafinil has been shown to improve fatigue associated with narcolepsy. ${ }^{48}$ As such, the athlete should not be disqualified. Of import is how much of this agent is necessary to effectively treat the medical condition. For if more than the required dosage were taken, would it mean that the athlete is in fact taking a performance enhancing agent beyond therapeutic treatment? This would require expert medical opinions.

There is no clear gold standard diagnosis for narcolepsy. Narcolepsy is clinically characterised by excessive daytime sleeping; polysomnography reveals the presence of sleep onset rapid eye movement periods during the multiple sleep latency test. ${ }^{47}{ }^{49}$ Recent research has shown the Epworth sleepiness scale (ESS) to be more discriminative than the multiple sleep latency test. ${ }^{50}$ Narcolepsy is a complex genetic disorder; family history of this condition, as was asserted in this case, may assist in diagnosis. ${ }^{47}{ }^{51}$ As such, proof of this medical condition should be based on clinical presentation. ESS, sleep studies, and HLA typing are diagnostic tools used to confirm this diagnosis. ${ }^{47} 495052$

The World Anti-doping Code (WADC) clearly addresses prohibited substances and exemptions.53 WADC defines potential inclusion in the prohibited substance: "medical or other scientific evidence, pharmacologic effect or experience that the substance or method has the potential to enhance or enhances sports performance" (4.3.1.1, p15). ${ }^{53}$ In addition, "WADA shall adopt an International Standard for the process of granting therapeutic use exemptions" (4.4, pl7). ${ }^{53}$ However, the key is the comment to 4.4 which states: "Athletes who use medically prescribed Prohibited Substances may be subject to sanctioning unless they have previously obtained a therapeutic use exemption" (4.4 Comment, p17)..$^{53}$ WADA further authorises the international federations (in the case of track and field this would be the IAAF) for granting or denying exemptions for international level athletes. ${ }^{53-55}$ IAAF clearly defines Control of Drug Abuse (Division III (Rules 55-61, pp 8291) $)^{54}$ and the appropriate procedure to obtain an exemption (Section 5, pl7)..$^{55}$ In this case, the athlete did not obtain the requisite exemption nor did she list modafinil as a medication she had taken on the urine samples tested.

Although fairness is sought in doping cases, a strict liability rule is usually applied. Perhaps the most telling case is that of a 16 year old Romanian gymnast who was stripped of the Sydney 2000 Olympic Games women's all-around gold medal when she tested positive for pseudoephedrine after taking OTC cold tablets. ${ }^{56}$ Although she was unaware of the presence of a prohibited substance (given by her team doctor), and although it made her dizzy and was not a performance enhancing agent, the Court of Arbitration for Sport confirmed that the athlete had committed a doping offence. ${ }^{56}$ Summary statements included: "This is what we call the strict liability rule-the consequences being the automatic disqualification as a matter of law and fairness to all other athletes. The fact that the drug may not have enhanced performance and the reliance on the team doctor are irrelevant." ${ }^{156}$ This gymnast won and was allowed to keep her individual vault silver medal; the finals for this event took place after the individual all-around disqualification. This is consistent with the current WADC: "If the Athlete establishes that he or she bares No Fault or Negligence for the violation, the Athlete's individual results in the other Competitions shall not be disqualified unless the Athlete's results in Competition other than the Competition in which the anti-doping rule violation occurred were likely to have been affected by the Athlete's antidoping rule violation" (10.1.1, p 26)..$^{53}$ This poses an ambiguity in the current situation-Kelli White was negligent for not filing an exemption; however, she was not negligent for taking a therapeutic agent for treatment of a medical condition. As such, it would appear to indicate that she should be disqualified from the $100 \mathrm{~m}$ but not the $200 \mathrm{~m}$ where she tested negative.

The prevalence of narcolepsy is only $0.02-0.05 \%$ in the United States. ${ }^{47}$ To have an elite athlete with narcolepsy would be rare; however, when the 2003 US Track and Field Championship urines were retested, a total of six athletes were reported positive for modafinil during 2003. ${ }^{57}$ Although Kelli White is the only athlete to state that she has narcolepsy, it is not surprising that the IAAF has scoffed at "a narcolepsy epidemic." ${ }^{158}$ Effective from 2004, modafinil has been added to the WADC banned list. ${ }^{59}$ Further, four US athletes tested positive for the new designer steroid tetrahydrogestrinone. ${ }^{60}$ 61 USATF has responded to these positive test results with proposed strict sanctions for athletes and coaches, significant financial fines, and lifetime bans for steroid offences. ${ }^{62}$

\section{CONCLUSION}

Whether modafinil is a "related substance" to stimulants remains unclear, especially in the domain of an athlete with a medical condition such as narcolepsy. From an ethical perspective, an athlete with a medical diagnosis should not be prevented from taking the appropriate medication, even if it is on the banned list. In this case, the critical issue is that the athlete did not request an exemption nor did she list this medication as having been taken. From a strict 


\section{Key points}

- Amateur athletics is premised on competition performed on an even playing field.

- Doping has led to the need for sanctions and specific anti-doping codes.

- Athletes with medical illnesses can compete when treated with banned or "related" substances if a medical exemption is obtained.

- The use of modafinil in athletics is addressed with the need to obtain a medical exemption and to have the appropriate diagnostic evaluation.

- Clinicians must be aware of those therapeutics that are banned or "related substances," treat the athlete accordingly, and assist the athlete in obtaining medical exemptions.

interpretation, sanctions apply, but it is felt most appropriate that these be limited to disqualification from the $100 \mathrm{~m}$. However, the existence of at least five more elite athletes with positive modafinil tests raises a serious red flag. Research studies are indicated to determine if modafinil is a performance enhancing agent. All athletes using modafinil should properly ask for exemptions, list this as a drug being taken, and have the appropriate medical diagnosis with supportive diagnostic procedures (sleep study, ESS). Amateur athletics, once the purest form of physical expression, should not be debased by doping; nor should medically ill athletes be prevented from competing on the same even playing field by being denied appropriate treatment.

Competing interests: none declared

\section{REFERENCES}

1 International Olympic Committee. Olympic Creed. http:// www.janecky.com/olympic/creed.html (accessed 27 March 2004).

2 International Olympic Committee. Olympic Oath. http://www.janecky.com/ olympic/oath.html (accessed 27 March 2004).

3 International Olympic Committee. Olympic Motto. http://www.janecky.com/ olympic/motto (accessed 27 March 2004).

4 Prendergast HM, Bannen T, Erickson TB, et al. The toxic torch of the modern Olympic Games. Vet Hum Toxicol 2003:45:97-102.

5 Franke WW, Beredonk B. Hormonal doping and androgenization of athletes: a secret program of the German Democratic Republic government. Clin Chem 1997;43:1262-79.

6 Cowan DA, Kicman AT. Doping in sport: analytical tests, and legal aspects. Clin Chem 1997:43:1110-13.

7 Eklof AC, Thurelius AM, Garle M, et al. The anti-doping hot-line, a means to capture the abuse of doping agents in the Swedish society and a new service function in clinical pharmacology. Eur J Clin Pharmacol 2003;59:571-7.

8 International Olympic Committee. Olympic Movement Anti-Doping Code. Lausanne, Switzerland: International Olympic Committee, 1999.

9 International Olympic Committee. Olympic Movement Anti-Doping Code Appendix A (in force as of 1 January 2003). http://www.cces.ca/WADAPUB-ProhibitedList2003-E.pdf (accessed 27 March 2004).

10 International Olympic Committee. Olympic Charter (in force as of 4 July 2003). http://multimedia.olympic.org/pdf/en_report_122.pdf (accessed 27 March 2004).

11 Roth T, Roehrs TA. Etiologies and sequelae of excessive daytime sleepiness. Clin Ther 1996;18:562-76.

12 Mitler MM, Harsh J, Hirshkowitz M, et al. Long-term efficacy of modafinil (Provigil) for the treatment of excessive daytime sleepiness associated with narcolepsy. Sleep Med 2000;1:231-43.

13 Schwartz JR, Hirshkowitz M, Erman MK, et al. Modafinil as adjunct therapy for daytime sleepiness in obstructive sleep apnea: a 12-week, open label study. Chest 2003;124:2192-9.

14 Menza MA, Kaufman KR, Castellanos AM. Modafinil augmentation of antidepressant treatment in depression. J Clin Psychiatry 2000;61:378-81.

15 DeBattista C, Lembke A, Solvason HB, et al. A prospective trial of modafinil as an adjunctive treatment of major depression. J Clin Psychopharmacol 2004;24:87-90.

16 Krupp LB. Fatigue in multiple sclerosis: definition, pathophysiology, and treatment. CNS Drugs 2003;17:225-34
17 MacDonald JR, Hill JD, Tarnopolsky MA. Modafinil reduces excessive somnolence and enhances mood in patients with myotonic dystrophy. Neurology 2002; 59:1876-80

18 Webster L, Andrews M, Stoddard G. Modafinil treatment of opioid-induced sedation. Pain Med 2003:4:135-40.

19 Nieves AV, Lang AE. Treatment of excessive daytime sleepiness in patients with Parkinson's disease with modafinil. Clin Neuropharmacol 2002;25: $111-14$

20 Hurst DL, Lajara-Nanson W. Use of modafinil in cerebral palsy. J Child Neurology 2002;17:169-72.

21 Rugino TA, Samsock TC. Modafinil in children with attention-deficit hyperactivity disorder. Pediatr Neurol 2003;29:136-42.

22 Kaufman KR, Menza MA, Fitzsimmons A. Modafinil monotherapy in depression. Eur Psychiatry 2002;17:167-9.

23 Turner DC, Robbins TW, Clark L, et al. Cognitive enhancing effects of modafinil in healthy volunteers. Psychopharmacology (Berl) 2003; 165:260-9

24 Xino YL, Fu JM, Dong Z, et al. Neuroprotective mechanism of modafinil on Parkinson disease induced by 1-methyl-4-phenyl-1,2,3,6-tetrahydropyridine. Acta Pharmacol Sin 2004;25:301-5.

25 Makris AP, Rush CR, Frederich RC, et al. Wake-promoting agents with different mechanisms of action: comparison of modafinil and amphetamine on food intake and cardiovascular activity. Appetite 2004;42:185-95.

26 Gold LH, Balster RL. Evaluation of the cocaine-like discriminative stimulus effects and reinforcing effects of modafinil. Psychopharmacology (Berl) 1996; 126:286-92.

27 Jasinski DR. An evaluation of the abuse potential of modafinil using methylphenidate as a reference. J Psychopharmacol 2000;14:53-60.

28 Camacho A, Stern MB. Modafinil for social phobia and amphetamine dependence. Am J Psychiatry 2002;159:1947-8.

29 Dackis C, O'Brien C. Glutamatergic agents for cocaine dependence. Ann N Y Acad Sci 2003:103:328-45.

30 Engber TM, Koury EJ, Dennis SA, et al. Differential patterns of regional c-Fos induction in the rat brain by amphetamine and the novel wakefulnesspromoting agent modafinil. Neurosci Lett 1998;241:95-8.

31 Lin JS, Hou Y, Jouvet M. Potential brain neuronal targets for amphetamine-, methylphenidate-, and modafinil-induced wakefulness, evidenced by c-fos immunocytochemistry in the cat. Proc Natl Acad Sci USA 1996;93:14128-33.

32 Scammell TE, Estabroke IV, McCarthy MT, et al. Hypothalamic arousal regions are activated during modafinil-induced wakefulness. J Neurosci 2000;20:8620-8.

33 Ferraro L, Tanganelli S, O'Connor WT, et al. The vigilance promoting drug modafinil increases dopamine release in the rat nucleus accumbens via the involvement of a local GABAergic mechanism. Eur J Pharmacol 1996:306:33-9.

34 Ferraro L, Antonelli T, O'Connor WT, et al. The antinarcoleptic drug modafinil increases glutamate release in thalamic areas and hippocampus. Neuroreport 1997;8:2883-7.

35 Ferraro L, Antonelli T, Tanganelli S, et al. The vigilance promoting drug modafinil increases extracellular glutamate levels in the medial preoptic area and the posterior hypothalamus of the conscious rat: prevention by local GABAA receptor blockade. Neuropsychopharmacology 1999;20:346-56.

36 Eriksson KS, Sergeeva OA, Selbach O, et al. Orexin (hypocretin)/dynorphin neurons control GABAergic inputs to tuberomammillary neurons. Eur J Neurosci 2004; 19:1278-84.

37 Ramsak B. I can only be Kelli White. http://www.iaaf.org/WCH03/news/ Kind $=2 /$ newsld-22919.html (accessed 27 March 2004).

38 Nichols P. White tests positive for stimulant. http://www.sport/ guardian.co.uk/athletics/story/0,10082,10032573,00.html (accessed 27 March 2004)

39 BBC Sport. White under investigation. http://news.bbc.co.uk/sportl/hi/ athletics/world_athletics-2003/3194041.stm (accessed 27 March 2004)

40 Nichols $\mathbf{P}$. White's second positive only serves to muddy waters. http:// timesonline.co.uk/printFriendly/0,1-7817-891835,00.html (accessed 27 March 2004)

41 Patrick D. IAAF probing Kelli White drug sample. http://usatoday.com/ sports/olympics/summer/track/2003-08-30-white-doping-probe_x.htm (accessed 27 March 2004).

42 IAAF Communication on the Kelli White Case 3 September 2003. http:// www . iaaf.org $/$ news $/$ Kind $=512 /$ newsld $=23089 . \mathrm{html}$ (accessed 27 March 2004).

43 IAAF Communication on the Kelli White Case 9 September 2003. http:// www. iaaf.org/news $/$ Kind $=512 /$ newsld $=23144$. html (accessed 27 March 2004).

44 Schwartz JR, Feldman NT, Fry JM, et al. Efficacy and safety of modafinil for improving daytime wakefulness in patients treated previously with psychostimulants. Sleep Med 2003;4:43-9.

45 Lagarde D, Batejat D, Van Beers P, et al. Interest of modafinil, a new psychostimulant, during a sixty-hour sleep deprivation experiment. Fundam Clin Pharmacol 1995;9:271-9.

46 Li YF, Zhan H, Xin YM, et al. Effects of modafinil on visual and auditory reaction abilities and subjective fatigue level during $48 \mathrm{~h}$ sleep deprivation. Space Med Med Eng (Beijing) 2003; 16:277-80.

47 Thorpy M. Current concepts in the etiology, diagnosis, and treatment of narcolepsy. Sleep Med $2001 ; 2: 5-17$.

48 Becker PM, Schwartz JR, Feldman NT, et al. Effect of modafinil on fatigue, mood, and health-related quality of life in patients with narcolepsy. Psychopharmacology (Berl) 2004;171:133-9.

49 Dauvilliers Y, Billiard M, Montplaisir J. Clinical aspects and pathophysiology of narcolepsy. Clin Neurophysiol 2003;114:2000-17. 
50 Johns MW. Sensitivity and specificity of the multiple sleep latency test (MSLT), the maintenance of wakefulness test, and the epsworth sleepiness scale: failure of the MSLT as a gold standard. J Sleep Res 2000;9:5-11.

51 Chabas D, Taheri S, Renier C, et al. The genetics of narcolepsy. Annu Rev Genomics Hum Genet 2003:4:459-83.

52 Silber MH, Krahn LE, Olson EJ. Diagnosing narcolepsy: validity and reliability of new diagnostic criteria. Sleep Med 2002;3:109-13.

53 World Anti-Doping Code (in force as of March 2003). http://www.wadaama.org/docs/web/statutes_harmonization/code/cod_v3.pdf)(accessed 27 March 2004)

54 IAAF. Control of drug abuse. http://www.tcaa.com.hk/tf/tf_download/iaaf/ 9899/hb9899_3.pdf (accessed 4 April 2004).

55 IAAF. Procedural Guidelines for Doping Control. http://www.sportspro.it/ doping/regolamenti/Reglaaf.pdf (accessed 4 April 2004).

56 O'Brien K. Sympathy but no medal for Romanian gymnast. http:// www.abc.net.au/7:30/s 192661.htm (accessed 4 April 2004).

57 BBC Sport. US officials admit drug tests. http://news.bbc.co.uk/sportl/hi/ athletics/3358253.stm (accessed 4 April 2004)

58 CBC Sports Online. IAAF official scoffs at "narcolepsy epidemic. " http:// www.cbc.ca/pcgi-bin/templates/sportsViewcgi?/news/2003/10/27/ Sports/modafinil_liungvist031027.htm (accessed 4 April 2004).

59 ABCsportonline. Two-year bans introduced for Modafinil use. http:// www.abc.net.au/sport/contents/s1034581.htm (accessed 4 April 2004)
60 Gloster R. USOC confirms Toth's THG, modafinil test. http:// www.usatoday.com/sports/olympics/summer/2004-02-16-usoc_x.htm (accessed 4 April 2004).

61 BBC Sport. The THG scandal explained. http://www.news.bbc.co.uk/sportl/ hi/athletics/3210876.stm (accessed 4 April 2004)

62 Gloster R. U.S. seeks tougher anti-drug standards. http://www.detnews.com/ 2003/moresports/0310/27/sports-305173.htm (accessed 4 April 2004).

\section{COMMENTARY}

This is a very timely consideration of the use of drugs that are necessary for an athlete's health, but which in other settings increase physical or mental ability. The requisite timely disclosure of the clinical appropriateness of a given treatment is discussed and is a foundation for sport medicine to build upon.

R Gerner UCLA, Topanga, CA, USA; rhgerner@aol.com

\section{Clinical Evidence - Call for contributors}

Clinical Evidence is a regularly updated evidence-based journal available worldwide both as a paper version and on the internet. Clinical Evidence needs to recruit a number of new contributors. Contributors are healthcare professionals or epidemiologists with experience in evidence-based medicine and the ability to write in a concise and structured way.

Areas for which we are currently seeking authors:

- Child health: nocturnal enuresis

- Eye disorders: bacterial conjunctivitis

- Male health: prostate cancer (metastatic)

- Women's health: pre-menstrual syndrome; pyelonephritis in non-pregnant women However, we are always looking for others, so do not let this list discourage you.

Being a contributor involves:

- Selecting from a validated, screened search (performed by in-house Information Specialists) epidemiologically sound studies for inclusion.

- Documenting your decisions about which studies to include on an inclusion and exclusion form, which we keep on file.

- Writing the text to a highly structured template (about 1500-3000 words), using evidence from the final studies chosen, within 8-10 weeks of receiving the literature search.

- Working with Clinical Evidence editors to ensure that the final text meets epidemiological and style standards.

- Updating the text every six months using any new, sound evidence that becomes available. The Clinical Evidence in-house team will conduct the searches for contributors; your task is simply to filter out high quality studies and incorporate them in the existing text.

- To expand the topic to include a new question about once every 12-18 months.

If you would like to become a contributor for Clinical Evidence or require more information about what this involves please send your contact details and a copy of your CV, clearly stating the clinical area you are interested in, to Klara Brunnhuber (kbrunnhuber@ bmigroup.com).

\section{Call for peer reviewers}

Clinical Evidence also needs to recruit a number of new peer reviewers specifically with an interest in the clinical areas stated above, and also others related to general practice. Peer reviewers are healthcare professionals or epidemiologists with experience in evidence-based medicine. As a peer reviewer you would be asked for your views on the clinical relevance, validity, and accessibility of specific topics within the journal, and their usefulness to the intended audience (international generalists and healthcare professionals, possibly with limited statistical knowledge). Topics are usually 1500-3000 words in length and we would ask you to review between 2-5 topics per year. The peer review process takes place throughout the year, and our turnaround time for each review is ideally 10-14 days.

If you are interested in becoming a peer reviewer for Clinical Evidence, please complete the peer review questionnaire at www.clinicalevidence.com or contact Klara Brunnhuber (kbrunnhuber@bmigroup.com). 